\title{
Differences between genotypes of tomato (Lycopersicon esculentum Mill.) in foliar contents of total phosphorus, total nitrogen and nitrate nitrogen, under low light intensity and low night temperatures
}

\section{S. J. van de Dijk}

Institute for Horticultural Plant Breeding (IVT), P.O. Box 16, 6700 AA Wageningen, Netherlands

Received 26 April 1985; accepted 9 September 1985

Key words: foliar nutrients, genotypes, low light intensity, low night temperatures, Lycopersicon esculentum, nitrate, nitrogen, phosphorus, tomato

\begin{abstract}
The contents of total phosphorus, total nitrogen and nitrate nitrogen were determined in the leaves of six genotypes of tomato (Lycopersicon esculentum Mill.) grown in pots with fertilized garden soil under low light intensity $\left(24 \mathrm{~W} \mathrm{~m}^{-2}\right)$, a day temperature of $19{ }^{\circ} \mathrm{C}$ and three night temperatures $\left(14^{\circ} \mathrm{C}, 10^{\circ} \mathrm{C}\right.$ and $\left.6{ }^{\circ} \mathrm{C}\right)$. Significant differences in nutrient contents between genotypes were established. Low night temperature caused a decrease in nitrogen and phosphorus contents but uptake of phosphorus and nitrogen, their subsequent translocation to the shoot and the rate of nitrate reduction did not seem to limit development in any of the genotypes and treatments.
\end{abstract}

\section{Introduction}

The present study has been conducted within the scope of a research project with tomato to evaluate the use of genotypic variation in physiological characters in breeding for adaptation to low light intensity and low temperature (Smeets \& Hogenboom, 1985). In previous experiments a growth analysis was carried out with 16 tomato genotypes grown in pots under short days, low light intensity and low night temperatures, $14{ }^{\circ} \mathrm{C}, 10^{\circ} \mathrm{C}$ and $6{ }^{\circ} \mathrm{C}$ (Smeets \& Garretsen, 1986). Genotypic differences in dry matter production were observed as well as genotype $\times$ night temperature interactions. The different growth response of the genotypes to low temperatures and low light intensity may be related to differences in uptake of phosphorus or nitrogen or in nitrate reduction. Reduced uptake of phosphorus at low temperatures has been observed in tomato by Locascio \& Warren (1960) and White (1981), reduced nitrogen uptake by Clarkson \& Warner (1979; for Lolium species) 


\section{S. J. VAN DE DIJK}

and a decreased nitrate reduction under low light intensity for different plant species by Beevers \& Hageman (1969).

The present paper deals with the effect of the night temperature and genotype on the content of total phosphorus, total nitrogen and nitrate nitrogen in the leaf blades of six of the previously used tomato genotypes when grown in pots with full nutrient supply. These data will provide an answer to the question whether these characters limit plant growth under low energy conditions and thus may explain differences in dry matter production between genotypes.

\section{Materials and methods}

\section{Plant material}

Six genotypes of tomato were used in the present investigation: Stupické polni and IVT-line 2 with moderate growth and good fruit set, Eurocross BB and Sonatine (hybrids) with vigourous growth and a moderate and rather good fruit set respectively, and Radio and Baby with moderate growth and bad fruit set under low light and low temperature conditions. Growth data of these genotypes were presented by Smeets \& Garretsen (1986).

\section{Experimental procedure}

Three temperature regimes (see below) were applied. Per temperature regime the plants were arranged in eight randomized blocks, each block containing six plots (genotypes) of eight plants. Five harvests were taken, per harvest 1 plant per plot. The age of the plants at the different harvests is indicated in Table 1. For the chemical analyses the leaf blades of four replicate plants of the second to the fifth harvest were used. For the phosphorus determinations the material of only the second and third harvest was used. For further details, see Smeets \& Garretsen (1986).

\section{Analyses of data}

The data for the different components of the different harvests were averaged per plot. This was done as for phosphorus and nitrate the contents remained constant during the experimental period. For the contents of total nitrogen and reduced nitrogen a small decrease was observed which was similar for all genotypes. Significant differences between genotypes were established with analyses of variance.

Table 1. Harvests in days after sowing for tomato leaves under different temperature regimes.

\begin{tabular}{lllll}
\hline Temperature regime & \multicolumn{1}{l}{ Harvest } & & \\
\cline { 2 - 5 } & 2 & 3 & 4 & 5 \\
$19^{\circ} \mathrm{C} / 14^{\circ} \mathrm{C}$ & 47 & 54 & 61 & 70 \\
$19^{\circ} \mathrm{C} / 10^{\circ} \mathrm{C}$ & 48 & 55 & 63 & 75 \\
$19^{\circ} \mathrm{C} / 6^{\circ} \mathrm{C}$ & 49 & 56 & 68 & 77 \\
\hline
\end{tabular}




\section{Growth conditions}

Seedlings were plotted 12 days after sowing in TRIO garden soil mixed with Osmocote slow release fertilizer ( $75 \mathrm{~g}$ per $80 \mathrm{l}$ soil) to provide a continuous non-limiting supply of plant nutrients. The pots were placed in climate rooms of the IVT phytotron (Smeets, 1978) at a light intensity of $24 \mathrm{~W} \mathrm{~m}^{-2}$ which is the average light intensity in December and January, and a daylength of $8 \mathrm{~h}$. During the first day after potting the temperature was maintained at $22^{\circ} \mathrm{C}$, during the second day at $19{ }^{\circ} \mathrm{C}$. Then a regime of $19{ }^{\circ} \mathrm{C} / 14{ }^{\circ} \mathrm{C}$ day/night temperature was applied. The relative humidity was $70 \%$. At 33 days after sowing the temperature regimes mentioned before, viz $19^{\circ} \mathrm{C} / 14^{\circ} \mathrm{C}, 19^{\circ} \mathrm{C} / 10{ }^{\circ} \mathrm{C}$ and $19^{\circ} \mathrm{C} / 6{ }^{\circ} \mathrm{C}$, were given. For further details, see Smeets \& Garretsen (1986).

\section{Chemical analyses}

All the leaf blades of whole plants were harvested, dried at $80^{\circ} \mathrm{C}$ and powdered. For total phosphorus and total nitrogen a sample was digested in sulfuric acid containing $60 \mathrm{~g} / \mathrm{l}$ of salicylic acid. The digests were analysed in a continuous-flow system as described for total nitrogen by van Ginkel \& Sinnaeve (1980) and for total phosphorus by Thomas et al. (1967). Aqueous extracts of the powdered material were analysed in the continuous-flow system according to Kamphake et al. (1967).

\section{Results}

The averages per genotype and per temperature regime of the contents of total phosphorus, total nitrogen, nitrate nitrogen and reduced nitrogen (the difference between total nitrogen and nitrate nitrogen), expressed as a percentage of the standard genotype Sonatine are given in Table 2.

Table 2. Contents of total phosphorus (averaged over two harvests), total nitrogen, nitrate nitrogen and reduced nitrogen (averaged over four harvests) in the leaves of six tomato genotypes grown under three night temperatures $\left(14{ }^{\circ} \mathrm{C}\right.$, $10^{\circ} \mathrm{C}$ and $6^{\circ} \mathrm{C}$ ). The values are expressed as a percentage of the standard genotype Sonatine. Figures indicated by the same letter are not significantly different $(P<0.05)$. The overall mean is expressed as a percentage of the dry matter.

\begin{tabular}{|c|c|c|c|c|c|c|c|c|c|c|c|c|}
\hline \multirow[t]{2}{*}{ Genotype } & \multicolumn{3}{|c|}{ Total phosphorus } & \multicolumn{3}{|c|}{ Total nitrogen } & \multicolumn{3}{|c|}{ Nitrate nitrogen } & \multicolumn{3}{|c|}{ Reduced nitrogen } \\
\hline & $14^{\circ} \mathrm{C}$ & $10^{\circ} \mathrm{C}$ & $6^{\circ} \mathrm{C}$ & $14^{\circ} \mathrm{C}$ & $10^{\circ} \mathrm{C}$ & $6^{\circ} \mathrm{C}$ & $14^{\circ} \mathrm{C}$ & $10^{\circ} \mathrm{C}$ & $6^{\circ} \mathrm{C}$ & $14^{\circ} \mathrm{C}$ & $10^{\circ} \mathrm{C}$ & $6{ }^{\circ} \mathrm{C}$ \\
\hline \multicolumn{13}{|l|}{ Eurocross } \\
\hline $\mathrm{BB}$ & $113 a$ & $121 \mathrm{a}$ & $128 b$ & $100 c$ & $104 \mathrm{c}$ & $104 c$ & $109 b c$ & $128 \mathrm{~cd}$ & $117 \mathrm{bc}$ & $99 b$ & $102 b$ & $104 c$ \\
\hline Baby & $113 \mathrm{a}$ & $119 \mathrm{a}$ & $131 \mathrm{ab}$ & $104 a b$ & $109 \mathrm{ab}$ & $109 b$ & $126 \mathrm{~b}$ & $144 \mathrm{bc}$ & $134 \mathrm{~b}$ & $102 \mathrm{ab}$ & $107 a$ & $107 \mathrm{~b}$ \\
\hline \multicolumn{13}{|l|}{ Stupické } \\
\hline polni & $111 \mathrm{a}$ & $118 \mathrm{a}$ & $128 b$ & $104 \mathrm{ab}$ & $108 \mathrm{ab}$ & $111 \mathrm{a}$ & $153 \mathrm{a}$ & $177 \mathrm{a}$ & $186 a$ & $100 \mathrm{~b}$ & $102 b$ & $107 b$ \\
\hline IVT-line 2 & $110 \mathrm{a}$ & $124 a$ & $134 a$ & $106 \mathrm{a}$ & $111 \mathrm{a}$ & $113 a$ & $117 \mathrm{bc}$ & $152 \mathrm{~b}$ & $138 \mathrm{~b}$ & $105 \mathrm{a}$ & $108 \mathrm{a}$ & $112 \mathrm{a}$ \\
\hline Radio & $104 b$ & $104 \mathrm{~b}$ & $111 \mathrm{c}$ & $103 b$ & $101 \mathrm{~cd}$ & $102 c$ & $103 c$ & 116de & $112 b c$ & $103 a b$ & $100 \mathrm{~b}$ & $102 \mathrm{~cd}$ \\
\hline Sonatine & $100 \mathrm{~b}$ & $100 \mathrm{~b}$ & $100 \mathrm{~d}$ & $100 \mathrm{c}$ & $100 \mathrm{~d}$ & $100 \mathrm{~d}$ & $100 \mathrm{c}$ & $100 \mathrm{e}$ & $100 \mathrm{c}$ & $100 \mathrm{~b}$ & $100 \mathrm{~b}$ & $100 \mathrm{~d}$ \\
\hline \multicolumn{13}{|l|}{ Overall } \\
\hline mean & 1.09 & 0.96 & 0.90 & 5.74 & 5.49 & 5.12 & 0.55 & 0.49 & 0.34 & 5.19 & 5.01 & 4.78 \\
\hline
\end{tabular}


With respect to all components the highest contents were observed under $19^{\circ} \mathrm{C} / 14{ }^{\circ} \mathrm{C}$ and the lowest under $19^{\circ} \mathrm{C} / 6^{\circ} \mathrm{C}$. No important genotype $\times$ temperature interactions were found. For all components considered here significant genotypic differences were present. Eurocross BB, Baby, Stupické polni and IVT-line 2 had the highest $P$ contents and Radio and Sonatine the lowest irrespective of the night temperature. For the three temperature regimes the highest contents of total nitrogen, nitrate and reduced nitrogen were observed in IVT-line 2, Baby and Stupické polni, the lowest in Radio, Eurocross BB and Sonatine. The differences were largest for nitrate nitrogen and relatively small for total nitrogen and reduced nitrogen. Stupické polni had a markedly high nitrate content under the three temperature regimes.

\section{Discussion}

Non-structural carbohydrates (soluble sugars and starch) are part of the total dry matter. Effects of night temperature and genotype on the contents of non-structural carbohydrates for the present genotypes were found previously (van de Dijk \& van Keulen, 1986). This may result in differences in the mineral contents which are due to differences in non-structural carbohydrate content. Therefore, the data of Table 2 were recalculated on the basis of structural dry matter. Since for carbohydrate determinations other replications were used than for chemical plant nutrient analyses only means per temperature regime and per genotype could be calculated and no statistical analyses could be carried out.

After this correction a negative effect of lower night temperature on the mineral contents still was obvious (Table 3), and the conclusion that lower night temperatures cause a decrease in uptake and translocation to the shoot of phosphorus and nitrogen might be valid. As regards genotypic differences under $19{ }^{\circ} \mathrm{C} / 14{ }^{\circ} \mathrm{C}$ and $19^{\circ} \mathrm{C} / 10^{\circ} \mathrm{C}$, no important changes occurred (data not presented). Under $19^{\circ} \mathrm{C} / 6{ }^{\circ} \mathrm{C}$ differences between genotypes became smaller for total phosphorus and nitrate nitrogen and nearly disappeared for total nitrogen and reduced nitrogen. Therefore, part of the differences in mineral contents between genotypes under $19{ }^{\circ} \mathrm{C} / 6{ }^{\circ} \mathrm{C}$ can be attributed to differences in non-structural carbohydrate content.

The mineral contents observed in our experiments are at the levels reported in

Table 3. Contents per night temperature of total phosphorus $(\mathrm{P})$, total nitrogen $(\mathrm{N})$, nitrate nitrogen $\left(\mathrm{NO}_{3}^{-}-\mathrm{N}\right)$ and reduced nitrogen (red-N) in tomato leaves as a percentage of total dry matter $(\% \mathrm{DM})$ and structural dry matter $\left(\% \mathrm{DM}_{\mathrm{s}}\right)$ for night temperatures 14,10 and $6{ }^{\circ} \mathrm{C}$.

\begin{tabular}{|c|c|c|c|c|c|c|}
\hline & \multicolumn{2}{|l|}{$14^{\circ} \mathrm{C}$} & \multicolumn{2}{|l|}{$10^{\circ} \mathrm{C}$} & \multicolumn{2}{|l|}{$6^{\circ} \mathrm{C}$} \\
\hline & $\% \mathrm{DM}$ & $\% \mathrm{DM}_{\mathrm{s}}$ & $\% \mathrm{DM}$ & $\% \mathrm{DM}_{\mathrm{s}}$ & $\% \mathrm{DM}$ & $\% \mathrm{DM}_{\mathrm{s}}$ \\
\hline $\mathbf{P}$ & 1.09 & 1.11 & 0.96 & 0.99 & 0.90 & 0.95 \\
\hline $\mathrm{N}$ & 5.74 & 5.84 & 5.49 & 5.64 & 5.12 & 5.41 \\
\hline $\mathrm{NO}_{3}^{-}-\mathrm{N}$ & 0.55 & 0.56 & 0.49 & 0.50 & 0.34 & 0.36 \\
\hline red-N & 5.19 & 5.28 & 5.01 & 5.15 & 4.78 & 5.05 \\
\hline
\end{tabular}


Table 4. Contents of total phosphorus $(\mathrm{P})$, total nitrogen $(\mathrm{N})$, nitrate nitrogen $\left(\mathrm{NO}_{3}^{-} \mathrm{N}\right)$ and reduced nitrogen (red-N) in leaves of six tomato genotypes grown under $6{ }^{\circ} \mathrm{C}$ night temperature as a percentage of total dry matter $(\% \mathrm{DM})$ and of structural dry matter $\left(\% \mathrm{DM}_{\mathrm{s}}\right)$.

\begin{tabular}{|c|c|c|c|c|c|c|c|c|}
\hline & \multicolumn{2}{|l|}{$\mathrm{P}$} & \multicolumn{2}{|l|}{$\mathrm{N}$} & \multicolumn{2}{|l|}{$\mathrm{NO}_{3}-\mathrm{N}$} & \multicolumn{2}{|l|}{ red-N } \\
\hline & $\% \mathrm{DM}$ & $\% \mathrm{DM}_{\mathrm{s}}$ & $\% \mathrm{DM}$ & $\% \mathrm{DM}_{\mathrm{s}}$ & $\% \mathrm{DM}$ & $\% \mathrm{DM}_{\mathrm{s}}$ & $\% \mathrm{DM}$ & $\% \mathrm{DM}_{\mathrm{s}}$ \\
\hline IVT-line 2 & 134 & 124 & 113 & 105 & 138 & 124 & 112 & 103 \\
\hline Baby & 131 & 124 & 109 & 103 & 134 & 128 & 107 & 102 \\
\hline $\begin{array}{l}\text { Stupické } \\
\text { polni } \\
\text { Eurocross }\end{array}$ & 128 & 118 & 111 & 104 & 186 & 172 & 107 & 100 \\
\hline $\mathrm{BB}$ & 128 & 122 & 104 & 100 & 117 & 110 & 104 & 99 \\
\hline Radio & 111 & 106 & 102 & 98 & 112 & 107 & 102 & 98 \\
\hline Sonatine & 100 & 100 & 100 & 100 & 100 & 100 & 100 & 100 \\
\hline $\begin{array}{r}\text { Overall } \\
\text { mean }\end{array}$ & 0.90 & 0.95 & 5.12 & 5.41 & 0.34 & 0.36 & 4.78 & 5.05 \\
\hline
\end{tabular}

the literature for healthy growing tomato plants (Table 5). The minimum phosphorus content observed by most authors in optimally growing plants is about $0.4 \%$. The content in the present plants was 0.9-1.09\%. Hence, no reduction of phosphorus uptake or translocation to the shoot which could impose a growth reduction is likely in any of the genotypes and treatments. For total nitrogen a similar conclusion can be drawn since contents of 5.0-5.84 \% in our experiments are of the same order as found in optimally growing plants (Table 5).

Nitrate reduction also did not limit plant growth in any of the genotypes and treatments since the content of reduced nitrogen is still in the range of the content of total nitrogen in optimally growing plants reported in the literature.

Table 5. Literature data on the contents of total phosphorus $(\mathrm{P})$ and total nitrogen $(\mathrm{N})$ in leaf tissue of tomato plants as a percentage of total dry matter. Values obtained in optimally growing plants (opt) and in plants showing growth reduction or deficiency symptoms $(\mathrm{min})$ are given.

\begin{tabular}{|c|c|c|c|c|}
\hline & \multicolumn{2}{|l|}{$P$} & \multicolumn{2}{|l|}{$\mathbf{N}$} \\
\hline & opt & $\min$ & opt & $\min$ \\
\hline Besford (1979) & $0.4-1.2$ & 0.13 & & \\
\hline Gosselin and Trudel (1983) & $1.1-1.6$ & & $5-5.8$ & \\
\hline Janssen et al. (1934) & 1.02 & 0.16 & 5.62 & 1.95 \\
\hline Lamb (1961) & 0.49 & & $3.28-5.09$ & \\
\hline Locascio \& Warren (1960) & $0.37-0.59$ & $0.18-0.27$ & & \\
\hline Smilde \& Roorda van Eysinga (1968) & $0.44-0.65$ & 0.18 & & \\
\hline Sobulo et al. (1975) & 0.4 & 0.15 & 4.2 & \\
\hline Ward (1963) & 0.8 & & 5.25 & \\
\hline White (1981) & $0.2-1.03$ & & & \\
\hline Winsor (1973) & 0.5 & & 4.8 & \\
\hline
\end{tabular}




\section{S. J. VAN DE DIJK}

Indications for differences between genotypes in mineral uptake and translocation are weak. Eurocross BB, a vigorously growing genotype, always had a high phosphorus content. This points to a rapid phosphorus uptake and translocation to the shoot. Sonatine, also a vigorous grower had a low content. Uptake and translocation of phosphorus in this genotype probably occurred at a lower rate than in Eurocross BB. IVT-line 2 had a high total nitrogen content under the three temperature regimes. However, this may reflect reduced growth rather than high uptake since production of IVT-line 2 is low, presumably as a result of carbohydrate limitation (van de Dijk \& van Keulen, 1986). The content of reduced nitrogen is about equal in the genotypes, especially after correction for soluble sugars and starch. Thus, no important differences in the rate of nitrate reduction became apparent.

It is concluded that uptake and translocation of nitrogen and phosphorus and reduction of nitrate did not cause the different growth performances (Smeets \& Garretsen, 1986) of the tomato genotypes used in this study and grown under low energy conditions.

\section{Acknowledgements}

The author wishes to acknowledge the cooperation of the project group 'Tomato physiology'. Thanks are also due to Dr H. Breteler of the Association Euratom ITAL, Wageningen and Mrs E. Fliervoet for help with the chemical analyses and to

Dr L. Smeets for critically reading the manuscript.

Financial support was given by the 'Commissie Energieverbruik' (Committee for Energy Consumption) of the Dutch Ministry of Agriculture and Fisheries.

\section{References}

Beevers, L. \& R. H. Hageman, 1969. Nitrate reduction in higher plants. Annual Review of Plant Physiology 20: 495-522.

Besford, R. T., 1979a. Uptake and distribution of phosphorus in tomato plants. Plant and Soil 51: 331340.

Besford, R. T., 1979b. Effect of phosphorus nutrition in peat on tomato plant growth and fruit development. Plant and Soil 51: 341-353.

Clarkson, D. T. \& A. J. Warner, 1979. Relationships between root temperature and the transport of ammonium and nitrate ions by italien and perennial ryegrass (Lolium multiflorum and Lolium perenne). Plant Physiology 64: 557-561.

Dijk, S. J. van de \& H. A. van Keulen, 1986. Differences between tomato genotypes (Lycopersicon esculentum Mill.) in the content of carbohydrates. Journal of Plant Physiology (in press).

Ginkel, J. H. van \& J. Sinnaeve, 1980. Determination of total nitrogen in plant material with Nessler's reagent by continuous-flow analysis. Analyst 105: 1199-1203.

Goodman, P. J., 1979. Genetic control of inorganic nitrogen assimilation of crop plants. In: E. J. Hewitt \& C. V. Cutting (Eds.), Nitrogen assimilation in plants, p. 165-181. Academic Press, London, ISBN 0-12-346360-2.

Gosselin, A. \& M. J. Trudel, 1983. Interactions between air and root temperatures on greenhouse tomato. II. Mineral composition of plants. Journal of the American Society for Horticultural Science 108: 905-909.

Janssen, G., R. R. Bartholomev and V. M. Watts, 1934. Some effects of nitrogen, phosphorus and potassium on the composition and growth of tomato plants. Arkansas Experiment Station, Bulletin 310: $1-43$. 
Kamphake, L. J., S. A. Hannah \& J. M. Cohen, 1967. Automated analysis for nitrate by hydrazine reduction. Water Research, 1: 205-216.

Lamb, J. G. D., 1961. Some effects of phosphate fertilizer on leaf composition in tomato. Irish Journal of Agricultural Research, 1: 73-80.

Locascio, S. J. \& G. F. Warren, 1960. Interaction of soil temperature and phosphorus on growth of tomatoes. Proceedings of the American Society for Horticultural Science 75: 601-610.

Smeets, L., 1978. The phytotron of the Institute for Horticultural Plant Breeding (IVT), Wageningen, the Netherlands. A revision of previous descriptions. Netherlands Journal of Agricultural Science 26: $8-12$.

Smeets, L. \& N. G. Hogenboom, 1985. Introduction to an investigation into the possibilities of using physiological characters in breeding tomato for low energy conditions. Euphytica 34: 705-707.

Smeets, L. \& F. Garretsen, 1986. Multivariate analysis of growth of tomato genotypes grown under low night temperatures and low light intensity. Euphytica (in press).

Smilde, K. W. \& J. P. N. L. Roorda van Eysinga, 1968. Nutritional diseases in glasshouse tomatoes. Pudoc, Wageningen, p. 13.

Sobulo, R. A., A. A. Fayemi \& A. Agboola, 1975. Nutrient requirements of tomatoes (Lycopersicon esculentum) in south west Nigeria. II. Foliar analysis for assessing nitrogen, phosphorus and potassium requirements. Experimental Agriculture 11: 137-143.

Thomas, R. L., R. W. Sheard \& J. R. Moyer, 1967. Comparison of conventional and automated procedures for nitrogen, phosphorus and potassium analysis of plant material using a single digestion. Agronomy Journal 59: 240-243.

Ward, G. M., 1963. The application of tissue analysis to greenhouse tomato nutrition. Proceedings of the American Society for Horticultural Science 83: 695-699.

White, R. A. J., 1981. Air temperature, soil warming and phosphorus nutrition of greenhouse tomatoes. Acta Horticulturae 115: 235-244.

Winsor, G. W., 1983. Nutrition. In: H. G. Kingham (Ed.), The U.K. tomato manual, p. 35-42. Grower Books, London, ISBN 0-901361-14-3. 